\title{
UPAYA MENINGKATKAN HASIL BELAJAR IPA DENGANMENERAPKAN MODEL WORD SQUARE BERBANTUAN MEDIA PAPAN LEMBAR BALIK PADA PESERTADIDIK KELAS V SDN 3 PALANGKA TAHUN PELAJARAN 2016/2017
}

\section{Oleh : Sarda Sari *Suniati, M.Pd*}

\begin{abstract}
Abstrak
Penelitian ini bertujuan untuk: (1) Mendeskripsikan akivitas belajar IPA peserta didik kelas V SDN-3 Palangka Tahun Pelajaran 2016/2017 pada penerapan model Word Square Berbantuan Media Papan Lembar Balik, (2) Meningkatkan hasil belajar IPA peserta didik kelas V SDN-3 Palangka Tahun Pelajaran 2016/2017 setelah penerapan model Word Square Berbantuan Media Papan Lembar Balik. Jenis penelitian yang digunakan peneliti adalah Penelitian Tindakan Kelas (PTK) dengan subjek penelitian seluruh peserta didik kelas V di SDN-3 Palangka yang berjumlah 32 peserta didik.Teknik Pengumpulan data dalam penelitian ini menggunakan observasi dan tes.Analisis data menggunakan analisis data kualitatif, kuantitatif dan Mixed Methods (Metode Gabungan). Hasil penelitian ini menunjukkan bahwa: (1) Aktivitas peserta didik kelas V SDN-3 Palangka tahun pelajaran 2016/2017 dalam pembelajaran IPA setelah menerapkan model pembelajaran Word Square Berbantuan Media Papan Lembar Balik menjadi sangat baik, karena peserta didik aktif, antusias, mendengarkan penjelasan guru serta bersemangat dalam mengikuti proses pembelajaran. Adapun hasil pengamatan akivitas guru pada kegiatan belajar mengajar yang dilakukan oleh pengamat I dan pengamat II selama proses pembelajaran IPA pada siklus I rata-rata aspek aktivitas guru 3,9 pada kategori sangat baik dan rata-rata aspek peserta didik yaitu 3,67 pada kategori sangat baik. (2) Ada peningkatan hasil belajar IPA dengan menerapkan model pembelajaran Word Square Berbantuan Media Papan Lembar Balik pada mata pelajaran IPA kelas V di SDN-3 Palangka tahun pelajaran 2016/2017. Hal ini ditunjukkan dengan hasil belajar yang dilihat melalui rata-rata kelas pada siklus I yaitu sebesar 84,22 dan presentase ketuntasan peserta didik sacara klasikal yaitu 100\%, dari ketetapan yang sudah ditentukan yaitu untuk KKM sebesar 65 dan kriteria ketuntasan secara klasikal 85\%. Dengan ini maka dapat disimpulkan bahwa ada peningkatan hasil belajar IPA setelah menerapkan model pembelajaran Word Square berbantuan Media Papan Lembar Balik.
\end{abstract}

Kata Kunci : Hasil Belajar IPA, Model Word Square dan Media Papan Lembar Balik 


\section{PENDAHULUAN}

IPA merupakan konsep pembelajaran alam dan sangat besar pengaruhnya terhadap perkembangan media serta pemahaman tentang alam semesta yang mempunyai banyak fakta dan masih banyak yang belum terungkap, tanpa pendidikan ilmu pengetahuan alam kiranya manusia tidak akan pernah menemukan penemuan-penemuan baru yang bermanfaat bagi kelangsungan hidup manusia. Pada mata pelajaran IPA hendaknya guru menggunakan model dan media pembelajaran yang mampu membuat peserta didik mengambarkan secara langsung dengan apa yang mereka pelajari.

Model pembelajaran sangat membantu guru dalam menyampaikan tujuan pembelajaran yang ingin dicapai. Menurut (Kurniasih \& Berlin, 2016:97) "Model Word square adalah yang memadukan kemampuan menjawab pertanyaan dengan kejelian dalam mencocokan jawaban pada kotak-kotak jawaban model ini sedikit lebih mirip dengan teka-teki silang tetapi bedanya jawabannya sudah ada namun disamarkan dengan menambahkan kotak tambahan dengan sembarang huruf/angka penyamar atau pengecoh". Model pembelajaran tidak lepas dari media pembelajaran.Media sangat berperan penting dalam memperjelas penyampaian pesan terhadap peserta didik, dengan media yang tepat dan bervariasi dapat mengatasi sikap pasif peserta didik. Menurut (Munadi, 2013:105) "media papan lembar balik adalah lembaran-lembaran kertas di mana terdapat gambar yang besar dapat dibalikkan pada sebuah gantungan, media papan lembar balik yaitu media menulis yang sangat hemat dan praktis yang digunakan dalam kegiatan tertentu atau lembaran kertas yang berisi pesan atau kumpulan ringkasan , skema, gambar, tabel dari suatu bahan materi pembelajaran yang tersusun rapi dan baik.

Berdasarkan hasil observasi yang dilakukan pada hari Senin, 21 November 2016 dan Sabtu 26 November 2016 di SDN-3 Palangka khususnya pada kelas V, permasalahan yang muncul pada waktu penyampaian materi pada mata pelajaran IPA berlangsung yaitu model dan media pembelajaran yang digunakan guru masih kurang bervariasi, sehingga membuat peserta didik kurang memahami materi pelajaran yang disampaikan, peserta didik merasa kurang bersemangat bahkan kebingungan dalam memahami pada saat proses belajar mengajar. Oleh karena itu ketika guru memberikan penilaian formatif khususnya pada mata pelajaran IPA yang suadah diajarkan ternyata hasilnya masih kurang memuaskan, dari 32 orang peserta 
didik yaitu 8 orang peserta didik (25\%) yang sudah menapai kriteria ketuntasan minimal $(\mathrm{KKM})$ yaitu dengan nilai ratarata 91,25 dan 24 orang peserta didik $(75 \%)$ yang masih belum mencapai kriteria ketuntasan minimal (KKM) yaitu dengan nilai rata-rata 48,25. Sedangkan nilai KKM mata pelajaran IPA yang telah ditentukan oleh sekolah adalah 65 .

Hal tersebut terjadi karena beberapa faktor diantaranya, pembelajaran IPA dilakukakan dengan metode yang kurang bervariasi, guru masih terpaku dengan cara mengajar di buku dalam menjelaskan kepada peserta didik tanpa adanya alat bantu sama sekali, proses pembelajaran yang masih cenderung konvensional dengan metode ceramah, tanya jawab, dan pemberian tugas dan terlihat jarang menggunakan model dan media saat kegiatan pembelajaran khususnya pada pelajaran IPA pada peserta didik kelas V SDN-3 Palangka.

\section{METODE PENELITIAN}

Jenis penelitian yang digunakan dalam penelitian ini adalah Penelitian Tindakan Kelas (PTK). Menurut Taggart (Muslich, 2012:8) "PTK adalah studi yang dilakukan untuk memperbaiki diri sendiri, pengalaman kerja sendiri, yang dilaksanakan secara sistematis, terencana, dan sikap meawas diri”.
Kehadiran peneliti sangat diperlukan dalam setiap kegiatan di tempat penelitian karena peneliti berperan sebagai perencana, pelakanaan tindakan, pengamat, reflector dan sebagai pelapor hasil penelitian. Sebagai subjek pemberi tindakan, peneliti bertindak sebagai pengajar atau guru model yang bertugas membuat rancangan pelaksanaan pembelajaran (RPP) sekaligus menyampaikan bahan ajar selama proses pembelajaran. Di samping itu, peneliti juga mengumpulkan dan menganalisis data serta sebagai pelapor hasil penelitian.

Subjek penelitian tindakan kelas ini adalah kelas V SDN-3 Palangka yang dilibatkan hanya satu kelas dengan jumlah peserta didik sebanyak 32 orang, yang meliputi 17 orang peserta didik laki-laki dan 15 orang peserta didik perempuan. Sedangkan yang menjad iobjek penelitian adalah hasil belajar IPA.

Pengumpulan data yang diperoleh pada penelitian ini dilakukan melalui pengamatan (observasi) dan tes hasil belajar.

Data yang dikumpulkan dari setiap siklus akan di analisis menggunakan metode Mixed Methods atau metode kombinasi antara kualitatif dan kuantitatif. Menurut Creswell dan Plano (Sanjaya 2012:49) menjelaskan mixed methods atau metode campuran adalah "pedoman pada 
arah dari kumpulan analisis data dan gabungan dari penelitian kualitatif dan kuantitatif dalam banyak fase pada proses penelitian".

Data kualitatif diperoleh dari aktivitas terhadap peneliti dan aktivitas terhadap peserta didik dan respon peserta didik selama proses belajar rmengajar dengan menganalisis hasil belajar yang dilihat dalam proses belajarmengajarmenggunakanmodel pembelajaran Word Square berbantuan media Papan Lembar Balik.

Data kuantitatif berasal dari hasil tes yang diberikan pada setiap akhir siklus kegiatan. Hal ini dilakukan untuk mengetahui peningkatan hasil belajar peserta didik pada pendekatan yang diterapkan.

\section{HASIL DAN PEMBAHASAN}

Data dari hasil penelitian ini berupa :

1) pengamatan aktivitas guru dan peserta didik.

2) hasil belajar IPA menggunakan model pembelajaranWord Square berbantuan media Papan Lembar Balik.

Tabel 1

\begin{tabular}{|l|l|l|}
\hline \multirow{2}{*}{ No } & \multirow{2}{*}{ Aktivitas } & Skor rata - rata \\
\cline { 3 - 3 } & & Siklus I \\
\hline 1 & Guru & 3,9 \\
\hline 2 & Peserta didik & 3,67 \\
\hline
\end{tabular}

Rekapitulasi Data Pengamatan

Observasi Aktivitas Guru dan Peserta didik

\section{Sumber data : Pengamatan Tahun 2016 (Dua orang observer)}

Berdasarkan tabel di atas, melalui kelas V SDN 3 Palangka aktivitas guru pembelajaran menggunakan model dan peserta didik menunjukan suatu pembelajaran Word Square berbantuan peningkatan yang baik dari observas media papan lembar balik oleh peneliti di Berdasarkan tabel hasil post test pada siklus I terlihat hasil belajar peserta didik

kelas V SDN-3 Palangka dengan rata-rata 84,22 dengan ketuntasan klasikal 
mencapai $100 \%$ ini berarti pada siklus ke I

ketuntasan belajar individu sudah mencapai dan dianggap tuntas, jadi tidak perlu ada tindakan selanjutnya untuk memperbaiki hasil belajar kelas V SDN-3 Palangka karena target dalam penelitian ini adalah standar KKM 65 sudah tercapai, dan tingkat ketercapaian ketuntasan hasil belajar peserta didik secara klasikalnya sudah melebihi target yang diinginkan, yaitu $85 \%$.

Adapun peningkatan hasil belajar dapat dilihat dalam gambar diagram berikut :

\section{Gambar 5}

Diagram Hasil Rekapitulasi Nilai Rata-Rata dan Ketuntasan Hasil Belajar IPA Peserta Didik Kelas V SDN 3 Palangka

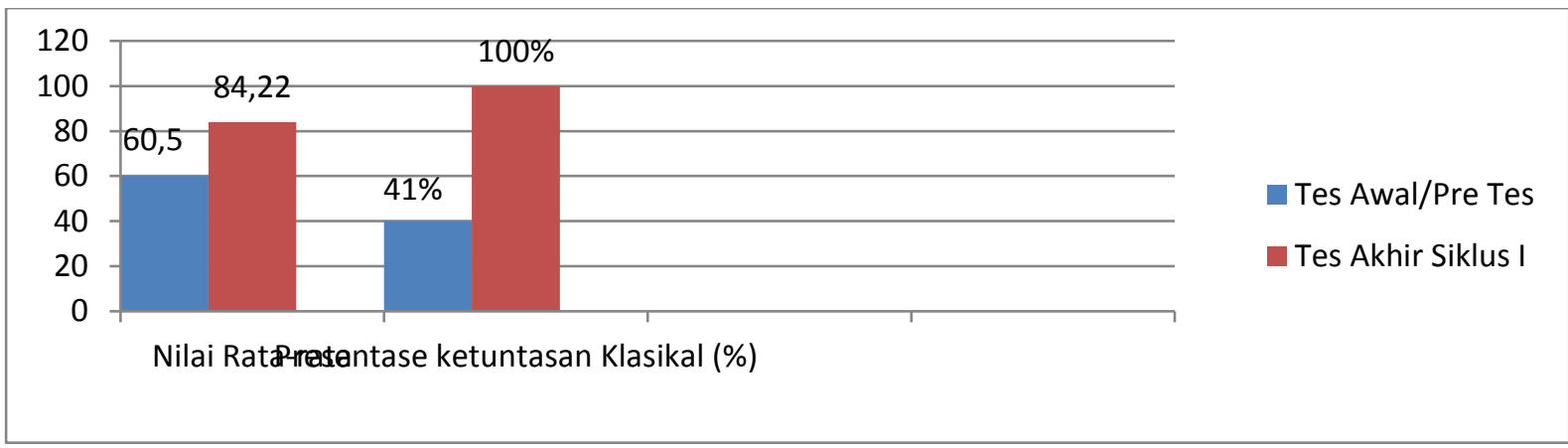

\section{SIMPULAN}

Berdasarkan hasil penelitian yang telah dibahas maka dapat disimpulkan:

1. Aktivitas peserta didik sangat baik selama proses pembelajaran IPA dengan menerapkan model word square berbantuan media papan lembar balik pada peserta didik kelas V SDN 3 Palangka tahun pelajaran 2016/2017. Dapat dilihat dari hasil pengamatan yang dilakukan oleh dua orang pengamat yang mendapatkan nilai rata-rata 3,67 dengan kriteria sangat baik.
2. Ada peningkatan hasil belajar IPA dengan menerapkan model word square berbantuan media papan lembar balik pada peserta didik kelas V SDN 3 Palangka tahun pelajaran 2016/2017. Peningkatan tersebut dilihat dari hasil belajar peserta didik pada mata pelajaran IPA khususnya pada materi gaya gravitasi bumi, gaya gesek dan gaya magnet. Dapat dilihat dari hasil tindakan mendapatkan nilai rata-rata 60,5. Sedangkan pada siklus I setelah diberikan tindakan hasil belajar peserta didik memperoleh nilai rata-rata 84,22 dengan ketuntasan klasikalnya 100\%. Hal 
Tunas Jurnal Pendidikan Guru Sekolah Dasar,Desember 2017, Volume 3 Nomor 1, (27-33) ISSN 2477-6076

tersebut telah mencapai indikator

keberhasilan penelitian yang telah

dtetapkan yaitu hasil belajar peserta didik

dengan KKM sebesar 65 dan ketuntasan

klasikalnya $85 \%$.

DAFTAR PUSTAKA

Kurniasih, Imas \& Berlin Sani. (2016).

Model Pembelajaran. Jakarta: Kata Pena 
Tunas Jurnal Pendidikan Guru Sekolah Dasar,Desember 2017, Volume 3 Nomor 1, (27-33) ISSN 2477-6076 